\title{
Is Ocean Acidification an Open-Ocean Syndrome? Understanding Anthropogenic Impacts on Seawater pH
}

\author{
Carlos M. Duarte • Iris E. Hendriks • Tommy S. Moore • \\ Ylva S. Olsen • Alexandra Steckbauer • Laura Ramajo • \\ Jacob Carstensen • Julie A. Trotter • Malcolm McCulloch
}

Received: 28 January 2013 / Accepted: 1 February 2013 / Published online: 1 March 2013

(C) Coastal and Estuarine Research Federation 2013

\begin{abstract}
Ocean acidification due to anthropogenic $\mathrm{CO}_{2}$ emissions is a dominant driver of long-term changes in $\mathrm{pH}$ in the open ocean, raising concern for the future of calcifying organisms, many of which are present in coastal habitats. However, changes in $\mathrm{pH}$ in coastal ecosystems result from a multitude of drivers, including impacts from watershed processes, nutrient inputs, and changes in ecosystem structure and metabolism. Interaction between ocean acidification due to anthropogenic $\mathrm{CO}_{2}$ emissions and the dynamic regional to
\end{abstract}

C. M. Duarte · I. E. Hendriks • T. S. Moore • Y. S. Olsen •

A. Steckbauer $\cdot$ L. Ramajo

Global Change Department, IMEDEA (CSIC-UIB), Instituto

Mediterráneo de Estudios Avanzados, C/ Miquel Marqués 21,

07190 Esporles (Mallorca), Spain

C. M. Duarte $(\bowtie) \cdot$ Y. S. Olsen

The UWA Oceans Institute and School of Plant Biology,

The University of Western Australia, 35 Stirling Highway,

Crawley 6009, Australia

e-mail: carlosduarte@ifisc.uib.es

\section{Ramajo}

Laboratorio de Ecologia y Cambio Climatico, Facultad de Ciencias Universidad Santo Tomas, C/ Ejercito 146,

Santiago de Chile, Chile

\section{J. Carstensen}

Department of Bioscience, Aarhus University,

Frederiksborgvej 399,

4000 Roskilde, Denmark

\section{J. A. Trotter}

School of Earth and Environment, The University of Western

Australia, 35 Stirling Highway,

Crawley 6009, Australia

\section{McCulloch}

ARC Centre of Excellence in Coral Reef Studies, School of Earth and Environment, The University of Western Australia,

35 Stirling Highway,

Crawley 6009, Australia local drivers of coastal ecosystems have resulted in complex regulation of $\mathrm{pH}$ in coastal waters. Changes in the watershed can, for example, lead to changes in alkalinity and $\mathrm{CO}_{2}$ fluxes that, together with metabolic processes and oceanic dynamics, yield high-magnitude decadal changes of up to 0.5 units in coastal $\mathrm{pH}$. Metabolism results in strong diel to seasonal fluctuations in $\mathrm{pH}$, with characteristic ranges of $0.3 \mathrm{pH}$ units, with metabolically intense habitats exceeding this range on a daily basis. The intense variability and multiple, complex controls on $\mathrm{pH}$ implies that the concept of ocean acidification due to anthropogenic $\mathrm{CO}_{2}$ emissions cannot be transposed to coastal ecosystems directly. Furthermore, in coastal ecosystems, the detection of trends towards acidification is not trivial and the attribution of these changes to anthropogenic $\mathrm{CO}_{2}$ emissions is even more problematic. Coastal ecosystems may show acidification or basification, depending on the balance between the invasion of coastal waters by anthropogenic $\mathrm{CO}_{2}$, watershed export of alkalinity, organic matter and $\mathrm{CO}_{2}$, and changes in the balance between primary production, respiration and calcification rates in response to changes in nutrient inputs and losses of ecosystem components. Hence, we contend that ocean acidification from anthropogenic $\mathrm{CO}_{2}$ is largely an open-ocean syndrome and that a concept of anthropogenic impacts on marine $\mathrm{pH}$, which is applicable across the entire ocean, from coastal to open-ocean environments, provides a superior framework to consider the multiple components of the anthropogenic perturbation of marine $\mathrm{pH}$ trajectories. The concept of anthropogenic impacts on seawater $\mathrm{pH}$ acknowledges that a regional focus is necessary to predict future trajectories in the $\mathrm{pH}$ of coastal waters and points at opportunities to manage these trajectories locally to conserve coastal organisms vulnerable to ocean acidification.

Keywords pH - Ocean acidification - Watershed changes · Eutrophication $\cdot$ Alkalinity $\cdot$ Anthropogenic impacts 


\section{Introduction}

Ocean uptake of anthropogenic $\mathrm{CO}_{2}$ is leading to a decline in the $\mathrm{pH}$ of the world's surface oceans (Caldeira and Wickett 2003, 2005; Orr et al. 2005; Raven et al. 2005). This process, driven by rapidly increasing anthropogenic $\mathrm{CO}_{2}$, is commonly referred to as "ocean acidification" (OA) is resulting in a decline in $\mathrm{CO}_{3}{ }^{2-}$ concentrations and, hence, the saturation state $(\Omega)$ of $\mathrm{CaCO}_{3}$ minerals in seawater, which is described by the equation

$\Omega=\left[\mathrm{Ca}^{2+}\right]\left[\mathrm{CO}_{3}{ }^{2-}\right] / K_{s p x}$

where $\left[\mathrm{Ca}^{2+}\right]$ and $\left[\mathrm{CO}_{3}{ }^{2-}\right]$ are the concentrations of dissolved calcium and carbonate ions in seawater and $K_{\mathrm{spx}}$ is the solubility constant for either aragonite or calcite, the forms of calcium carbonate commonly formed by some shell-forming organisms. The realized and projected decline in seawater, $\Omega$, has caused concern for the future of calcifying organisms (Caldeira and Wickett 2003, 2005; Orr et al. 2005; Raven et al. 2005, Doney et al. 2009). Marine life vulnerable to OA include open-ocean species, such as coccolithophores, pelagic mollusks and foraminifera, among others, but the greatest concern is with coastal calcifying organisms, including bivalves, shallow-water calcareous algae and particularly corals (Doney 2006, Doney et al. 2009).

The potential impact of OA on coastal organisms has been inferred largely from experiments where the performance of organisms under the $\mathrm{pCO}_{2}$ and $\mathrm{pH}$ conditions predicted for the open ocean in year 2100 (Doney et al. 2009; Ries et al. 2009; Hendriks et al. 2010a; Kroeker et al. 2010) have been determined and compared to the observed responses of coastal calcifying organisms to present (e.g. Waldbusser et al. 2011, Barton et al. 2012) and past situations of low pH (e.g. Pelejero et al. 2010; Hönisch et al. 2012). However, the conditions predicted for the open ocean may not reflect the future conditions in the coastal zone, where many of these organisms live (Hendriks et al. 2010a, b; Hofmann et al. 2011; Kelly and Hofmann 2012), and results derived from changes in $\mathrm{pH}$ in coastal ecosystems often include processes other than $\mathrm{OA}$, such as emissions from volcanic vents, eutrophication, upwelling and longterm changes in the geological cycle of $\mathrm{CO}_{2}$, which commonly involve simultaneous changes in other key factors affecting the performance of calcifiers, thereby confounding the response expected from $\mathrm{OA}$ by anthropogenic $\mathrm{CO}_{2}$ alone.

Coastal ecosystems are complex as coastal biogeochemical dynamics are governed by interactions between processes on land, in the open ocean and the atmosphere (Aufdenkampe et al. 2011), many of them affected by anthropogenic processes. Unlike pelagic ecosystems, coastal ecosystems are often dominated by benthic ecosystems, including engineering species (e.g. corals, seagrass, macroalgae, salt marshes, mangroves, sponges, oyster reefs) with the capacity to modulate the chemical and physical conditions of their environment (Gutiérrez et al. 2011). These factors interact in the coastal ocean, so the coastal zone carbon system is more dynamic and complex than that of the open ocean (Borges and Gypens 2010; Cai 2011).

In particular, anthropogenic $\mathrm{CO}_{2}$ inputs may play a smaller role relative to other sources of $\mathrm{pH}$ variability, natural and anthropogenic, in the coastal ocean as compared to the open ocean (e.g. Borges and Gypens 2010; Provoost et al. 2010; Cai et al. 2011; Hofmann et al. 2011). Hence, how the $\mathrm{pH}$ of coastal ecosystems in year 2100 will differ from current ones is difficult to predict due to lack of understanding of the average values and their variability in current environments and of the future trajectories of the multiple factors affecting coastal $\mathrm{pH}$ compared to the open ocean. Furthermore, understanding the dynamics of coastal $\mathrm{pH}$ and the carbon system is important to assess the conditions under which vulnerable coastal organisms evolved (Hendriks et al. 2010a, b; Hofmann et al. 2011; Kelly and Hofmann 2012). Thus, our awareness of the variability and complexity of $\mathrm{pH}$ regulation in the coastal ocean is currently disconnected from OA projections, which are based on general circulation models (GCMs) focused on anthropogenic $\mathrm{CO}_{2}$ as the main driver, with little capacity to resolve the coastal ocean.

Here, we formulate an alternative, more holistic concept of anthropogenic impacts on seawater $\mathrm{pH}$. Although the concept of OA by anthropogenic $\mathrm{CO}_{2}$ has played a key role in alerting us of the challenges facing calcifying organisms resulting from declines in $\mathrm{pH}$, we believe that this concept fails to provide a realistic framework addressing anthropogenic forcing of $\mathrm{pH}$ in coastal waters. In particular, we formulate the thesis that the current concept of OA by anthropogenic $\mathrm{CO}_{2}$ should be subsumed within a broader, more encompassing paradigm of anthropogenic impacts on marine $\mathrm{pH}$.

This new concept of anthropogenic impacts on seawater $\mathrm{pH}$ formulated here accommodates the broad range of mechanisms involved in the anthropogenic forcing of $\mathrm{pH}$ in coastal ecosystems, including changes in land use, nutrient inputs, ecosystem structure and net metabolism, and emissions of gases to the atmosphere affecting the carbon system and associated $\mathrm{pH}$. The new paradigm is applicable across marine systems, from open-ocean and ocean-dominated coastal systems, where $\mathrm{OA}$ by anthropogenic $\mathrm{CO}_{2}$ is the dominant mechanism of anthropogenic impacts on marine $\mathrm{pH}$, to coastal ecosystems where a range of natural and anthropogenic processes may operate to affect $\mathrm{pH}$.

Drawing a parallel with progress in understanding human perturbations to the carbon cycle, our approach in assessing anthropogenic impacts on seawater $\mathrm{pH}$ is to separate the regulation of $\mathrm{pH}$ in ocean surface waters into two modesregulation in the pre-disturbance Holocene ocean and anthropogenic processes regulating $\mathrm{pH}-$ with the interplay between 
both components acting to regulate seawater $\mathrm{pH}$ in the Anthropocene.

\section{Regulation of Seawater pH in the Pre-disturbed Holocene Ocean}

Proxy reconstructions indicate that oceanic $\mathrm{pH}$ has remained relatively uniform over the past $20 \mathrm{Myr}$ (Pearson and Palmer 2000; Pagani et al. 2005) compared to present and projected changes. Marine $\mathrm{pH}$ in the pre-disturbed Holocene, referring to the centuries preceding the industrial revolution, was regulated by a complex array of factors acting upon marine acid/base chemistry and the associated carbonate buffering system, mostly through variabilities in $\mathrm{CO}_{2}$, DIC and $\mathrm{Ca}^{2+}$ fluxes (Table 1). Long-term geological processes, particularly those involving silicate weathering, are relevant at scales of hundreds of thousands of years and need not, therefore, be considered here. At the global scale, major processes include global metabolic processes, ocean ventilation and volcanic emissions, affecting the atmospheric concentration of $\mathrm{CO}_{2}$ and hence the equilibrium concentration in ocean waters, and carbonate weathering on land and the associated discharge, through rivers and groundwater, of $\mathrm{Ca}^{2+}$, carbonate alkalinity, and inorganic and organic carbon to the ocean (Aufdenkampe et al. 2011; Table 1).

The $\mathrm{pH}$ in surface open-ocean waters was regulated largely by changes in $\mathrm{CO}_{2}$ because the carbonate ion concentration $\left(\mathrm{CO}_{3}{ }^{-}\right)$concentration is relatively uniform over the timescales of interest and ocean waters are mostly saturated in $\mathrm{Ca}^{2+}$ (Caldeira and Berner 1999). However, large changes occurred over longer (100 Myr) timescales (Tyrrell and Zeebe 2004). $\mathrm{CO}_{2}$ concentrations, in turn, were regulated by metabolic processes and $\mathrm{CO}_{2}$ exchanges with the atmosphere and deeper waters (Falkowski et al. 2000).

In contrast, the regulation of $\mathrm{pH}$ in surface coastal waters is far more complex as it depends on the processes affecting $\mathrm{pH}$ in the open ocean as well as watershed inputs of $\mathrm{Ca}^{2+}$, carbonate alkalinity, inorganic and organic carbon and nutrients, and ecosystem metabolism as well as hydrological processes that dictate the mixing between open ocean and coastal waters (Table 1). Watershed effects depend, in turn, on the climatic, hydrological and geological regimes as well as the dynamics of the ecosystems in the watershed (Aufdenkampe et al. 2011). Seepage of groundwater can lead to areas of high $\mathrm{pCO}_{2}$ and low $\mathrm{pH}$ in coastal ecosystems (Basterretxea et al. 2010). Groundwater with a low carbonate saturation state $(\Omega \approx 0.5)$ and reduced $\mathrm{pH}(6.70-7.30)$ seeps through the seafloor, creating localized low seawater $\mathrm{pH}$ in the natural submarine groundwater springs at Puerto Morales, Mexico (Crook et al. 2012). Submarine volcanic vents or groundwater seeps can also lead to high $\mathrm{CO}_{2}$ and low $\mathrm{pH}$ in surface coastal waters. Volcanic $\mathrm{CO}_{2}$ vents produce shallow-water gradients of $\mathrm{pH}$ across tens of meters, reaching values as low as 6.6-6.8 in the Mediterranean, for example around the most active vents in Ischia and Vulcano Islands, Italy (Hall-Spencer et al. 2008; Johnson et al. 2013) and $\mathrm{pH}$ values $<7.7$ (as low as 7.21) in volcanic seeps in Papua New Guinea (Fabricius et al. 2011). Natural gradients in $\mathrm{pH}$ exists across a distance of $<100 \mathrm{~m}$ from these volcanic $\mathrm{CO}_{2}$ vents, where the $\mathrm{pH}$ increases to normal seawater values of 7.97-8.14 (Hall-Spencer et al. 2008; Johnson et al. 2013; Fabricius et al. 2011). Volcanic eruptions may lead to extreme $\mathrm{pH}$, such as the 6.2 values recorded in coastal waters following an underwater eruption giving rise to a novel shallow submarine volcano south of the island of El Hierro, Canary Islands, Spain (Fraile-Nuñez et al. 2012).

Metabolic effects, represented by net community production and calcification rates, tend to be order of magnitude greater in coastal than in open-ocean ecosystems (Duarte and Cerbrian 1996; Gattuso et al. 1998) and play a major role in the $\mathrm{pH}$ control of coastal and estuarine ecosystems (Anthony et al. 2011; Table 2). Observations of $\mathrm{pH}$ in a variety of coastal habitats indicate characteristic site-specific diel, semi-diurnal and stochastic patterns of varying amplitudes
Table 1 Summary of processes driving changes in surface water $\mathrm{pH}$ in marine ecosystems

\begin{tabular}{lll}
\hline Driver & Pre-disturbance & Anthropogenic disturbance \\
\hline Air-sea exchange & Air-sea $\mathrm{CO}_{2}$ exchange & $\begin{array}{l}\text { Ocean uptake of anthroporgenic } \mathrm{CO}_{2} \\
\text { Deposition of anthropogenic acids and bases } \\
\text { Watershed processes }\end{array}$ \\
& Weathering & Mining \\
& Volcanic activity & Acid sulphate soil disturbance \\
& Ecosystem processes & Changes in land use \\
& Climatic variability & Agricultural practices \\
& & Melting and thermokarst processes \\
& & Hydrological perturbations \\
& & Anthropogenic climate change \\
Ecosystem processes & Community metabolism & Eutrophication \\
& Mixing and water residence time & Habitat loss \\
& & Anthropogenic climate change \\
\hline
\end{tabular}




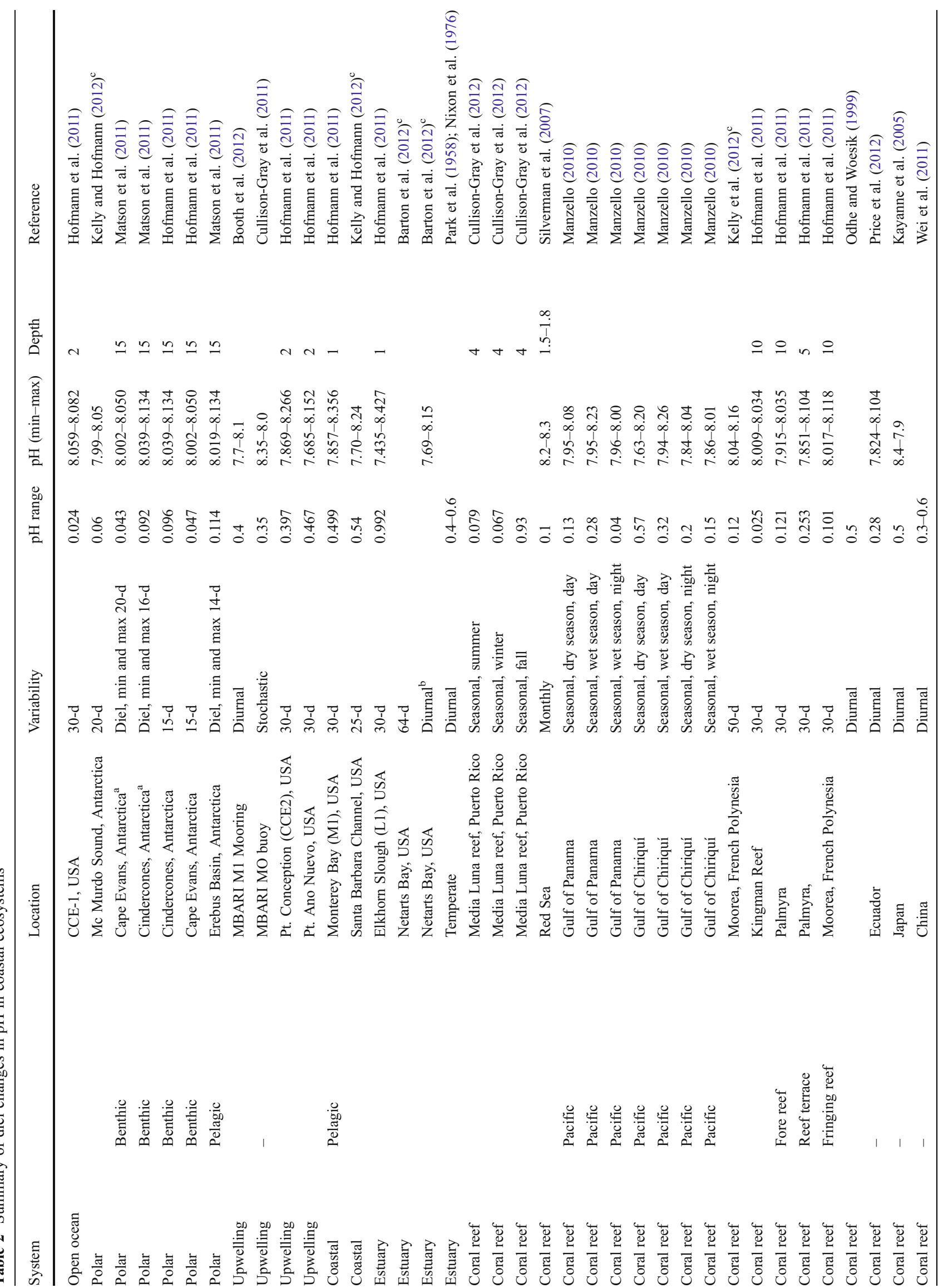




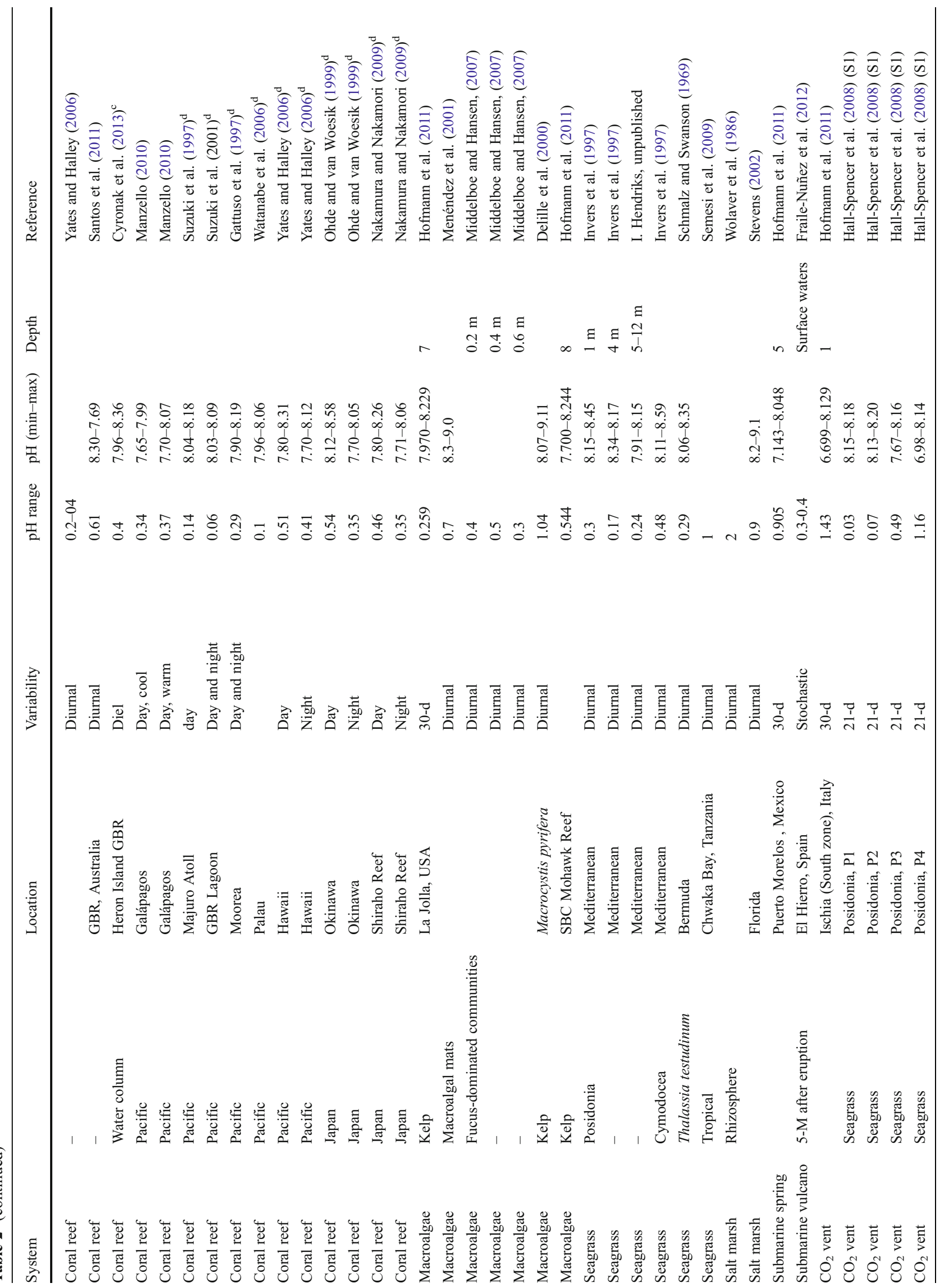




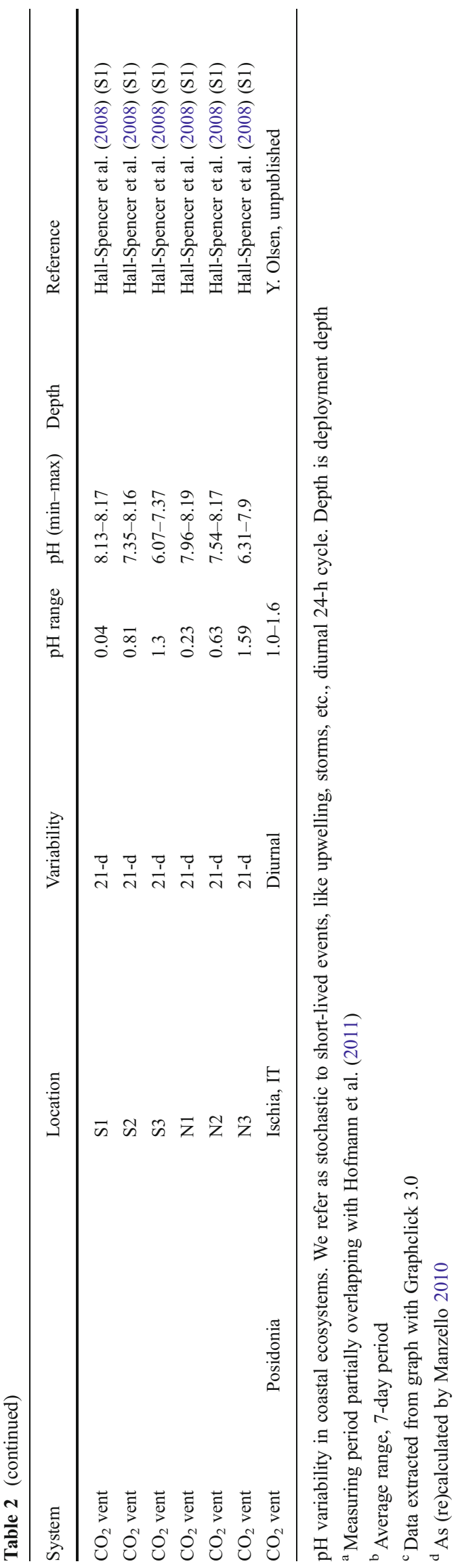

(Hofmann et al. 2011; Table 2). Metabolic-intense ecosystems, such as seagrass meadows, mangroves, salt marshes, coral reefs and macroalgal beds, can support diel changes in $\mathrm{pH}$ as high as 1.0 unit (Table 2). Coastal phytoplankton blooms can also modify water column $\mathrm{pH}$ significantly, with $\mathrm{pH}$ increasing to 8.6-9.0 during phytoplankton blooms (Brussaard et al. 1996; Spilling 2007; Dai et al. 2008). Conversely, the collapse and subsequent remineralization of phytoplankton blooms can lead to substantial drops in $\mathrm{pH}$, such as a seasonal decline in $\mathrm{pH}$ of $0.3-0.4$ units reported in bottom waters at Seto Inland Sea, Japan (Taguchi and Fujiwara 2010), and Bohai Sea, China (Zhai et al. 2012).

Benthic microbial processes can also modify alkalinity and $\mathrm{pH}$ through sediment-water fluxes in coastal ecosystems (Cyronak et al. 2013). The primary process affecting alkalinity in anoxic sediments is bacterial sulfate reduction, which may supersaturate pore waters with $\mathrm{CaCO}_{3}$ (Berner et al. 1970; Hines et al. 1989). Net alkalinity gain is, however, only achieved during anaerobic processes that involve a permanent loss of remineralization products, e.g. through denitrification or pyrite burial (Hu and Cai 2003). Vegetation modifies sediment biogeochemical processes and, thus, affects the $\mathrm{pH}$ and alkalinity of pore waters. Rapid changes in subsurface biogeochemical processes measured in a New England salt marsh coincided with temporal variations in the physiology of Spartina alterniflora (Hines et al. 1989). Sulfate reduction rates increased fivefold during phases of active plant growth, probably fueled by dissolved organic matter released from the plant roots.

In summary, surface water $\mathrm{pH}$ in open ocean locations is relatively stable, with a narrow range of variability, typically at $<0.1 \mathrm{pH}$ units inter-annually (e.g. Doney et al. 2009), compared to high variability, of as much as $1 \mathrm{pH}$ unit, in coastal ecosystems at scales ranging from diel (e.g. Hofmann et al. 2011; Table 2), driven by the metabolic signal to seasonal and decadal oscillations with amplitudes $>0.3 \mathrm{pH}$ units (e.g. Borges and Gypens 2010; Provoost et al. 2010; Barton et al. 2012; Cai et al. 2011; Hofmann et al. 2011; Mercado and Gordillo 2011; Waldbusser et al. 2011; Melzner et al. 2013; Fig. 1). In addition, as most rivers are acidic, and have saturation states for aragonite $(\Omega)$ lower than receiving ocean waters, dynamic gradients in $\mathrm{pH}$ and $\Omega$ exist along salinity gradients in coastal waters, which sometimes show conservative behaviour, dominated by mixing processes (e.g. Salisbury et al. 2008), but can be affected by in situ metabolic processes, deviating from conservative behaviour, in others (e.g. Cai et al. 2011).

Hence, the regulation of $\mathrm{pH}$ and $\Omega$ can be modelled by considering a three end-member system: open-ocean and freshwater end-members and ecosystem metabolism, the later not being properly an end-member but a process causing deviation from the open ocean to freshwater conservative mixing line (e.g. Guo et al. 2012). Ocean-dominated systems, such as the open-ocean and coastal ecosystems 


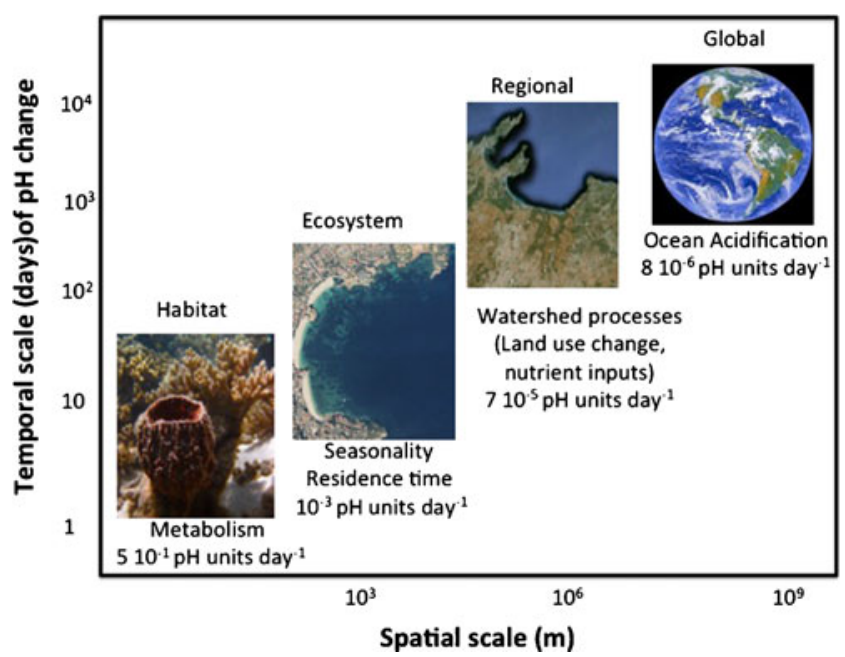

Fig. 1 Conceptual diagram showing the multiple processes contributing to variability in $\mathrm{pH}$ in coastal ecosystems across domains with scales spanning from patch to global and day to century. The rate values correspond to the characteristic rate of change in $\mathrm{pH}$ for the various domains

adjacent to arid land (e.g. those in Antarctica and adjacent to arid regions, such as NW Australia; Falter et al. 2013) and very small watersheds, such as those in atolls and small islands, will likely reflect the open-ocean $\mathrm{pH}$ and $\Omega$ dynamics (Falter et al. 2013). River-dominated systems will reflect the dynamics of the freshwater end-member, and the deviation of coastal ecosystems supporting intense metabolism from the conservative mixing lines delineated by the openocean and freshwater end-members will depend on water residence time and mixing processes (Anthony et al. 2011; Falter et al. 2013). Hence, use of coastal typologies, which consider the elements above, has led to an improved capacity to represent and integrate ocean biogeochemistry and $\mathrm{CO}_{2}$ fluxes (Laruelle et al. 2010) and may help identify contrasting modes of $\mathrm{pH}$ and $\Omega$ regulation in coastal waters.

\section{Regulation of Open-Ocean and Coastal pH in the Anthropocene}

The rapid increase in the capacity of humans to impact the key processes regulating the functioning of the biosphere into the Anthropocene (Steffen et al. 2007) has extended to a capacity to impact marine $\mathrm{pH}$ (Table 1). Human activities can act on marine $\mathrm{pH}$ through impacts propagated through the atmosphere, freshwater discharges and direct impacts on ecosystem components (Table 1). Accordingly, there are three main vectors of anthropogenic impacts on marine $\mathrm{pH}$ : (1) emissions of $\mathrm{CO}_{2}$, and other gases affecting marine $\mathrm{pH}$, to the atmosphere; (2) perturbation of watershed processes affecting the inputs of nutrients, organic and inorganic carbon, acids and carbonate alkalinity to the ocean; and (3) impacts on ecosystem structure (Table 1). These drivers add to the processes operating prior to the human perturbation to regulate marine $\mathrm{pH}$ in the Anthropocene.

Impacts of Anthropogenic $\mathrm{CO}_{2}$ Emissions on Seawater $\mathrm{pH}$

The impacts on marine $\mathrm{pH}$ derived from anthropogenic $\mathrm{CO}_{2}$ emissions have received the greatest attention and have led to a growing spectrum of research programs focused around the paradigm of OA by anthropogenic $\mathrm{CO}_{2}$ (Caldeira and Wickett 2003; Raven et al. 2005; Doney et al. 2009). $\mathrm{CO}_{2}$ emissions from the burning of fossil fuels and land use change since the industrial revolution have caused an increase in atmospheric $\mathrm{CO}_{2}$ concentrations from 280 to $390 \mathrm{ppm}$ (globally averaged mean surface value for 2011; Thomas Conway and Pieter Tans, NOAA/ESRL, www.esrl.noaa.gov/gmd/ccgg/trends/). The global oceans have absorbed about $40 \%$ of the anthropogenic carbon emissions (Sabine and Tanhua 2010), leading to a decline in $\mathrm{pH}$ evident in surface open-ocean time series (Caldeira and Wickett 2003; Raven et al. 2005; Doney et al. 2009). In addition to impacting surface water $\mathrm{pH}$, accumulation of anthropogenic carbon in deeper waters is leading to shoaling of the horizon for aragonite saturation (Feely et al. 2010). Accordingly, upwelling of waters acidified by anthropogenic $\mathrm{CO}_{2}$ has led to a further decrease in surface $\mathrm{pH}$, as reported in the eastern Pacific Ocean along the west coast of North America, from central Canada to northern Mexico, where shoaling of the layer of seawater undersaturated with aragonite increased the frequency and magnitude of coastal acidification associated with upwelling events (Feely et al. 2008, 2010).

Human emissions of reactive sulfur and nitrogen, derived from fossil fuel combustion and agriculture, have led to increased deposition of strong acids $\left(\mathrm{HNO}_{3}\right.$ and $\left.\mathrm{H}_{2} \mathrm{SO}_{4}\right)$ and bases $\left(\mathrm{NH}_{3}\right)$ to the ocean, hence affecting seawater $\mathrm{pH}$ (Doney et al. 2007). Whereas these effects on open-ocean $\mathrm{pH}$ are calculated to be minor, they can be higher, at rates of $0.02-0.12 \times 10^{-3} \mathrm{pH}$ units per year $(<10 \%$ of OA by anthropogenic $\mathrm{CO}_{2}$ ), in coastal ecosystems (Doney et al. 2007), where atmospheric deposition is intense and the waters can be more weakly buffered.

Impacts of Anthropogenic Watershed Perturbations on Seawater $\mathrm{pH}$

Changes in land use over the past centuries have affected the biogeochemical cycles of carbon and nutrients in the coastal zone strongly (Nixon 1995; Doney 2010; Hooke and MartínDuque 2012). In particular, human activity has altered the watershed export of organic and inorganic carbon, carbonate alkalinity, acids and nutrients to the ocean, affecting $\mathrm{pH}$ (Aufdenkampe et al. 2011). However, these impacts are largely restricted to the coastal ocean, where these inputs are received. 
Deforestation, agricultural (Oh and Raymond 2006), mining (Brake et al. 2001; Raymond and Oh 2009) and urban/suburban practices (Barnes and Raymond 2009) were linked to direct changes in the delivery of buffering capacity to streams and rivers. These changes have the potential to alter the concentrations of inorganic $\mathrm{C}$ species expected through the mixing of freshwater and seawater in estuaries, thereby affecting $\mathrm{pH}$ in coastal water (Aufdenkampe et al. 2011). Mining activities typically yield an increase in acid export, leading to a decline in $\mathrm{pH}$ in the receiving coastal waters (Brake et al. 2001; Raymond and Oh 2009). In an extreme example, a $\mathrm{pH}$ of $<3$ was reported in the estuarine reaches of the Río Tinto estuary, SW Spain (Elbaz-Poulichet et al. 1999). Alteration of tropical acid sulphate soils also releases large amounts of acids (Wilson et al. 1999; Johnston et al. 2009), affecting coastal waters containing vulnerable organisms, such as corals in the inner Great Barrier Reef ecosystem (Powell and Martens 2005).

Watershed processes, including export of alkalinity, derived from the weathering of carbonate rock and the use of lime in agriculture to reduce soil acidity (West and McBride 2005) can affect the magnitude of the alkalinity buffer in coastal waters. Changes in land use and increasing precipitation and/or runoff can also enhance alkalinity export from land to coastal ecosystems through chemical weathering (Raymond et al. 2008). These changes may counteract the tendency for $\mathrm{pH}$ to decline from $\mathrm{OA}$ due to anthropogenic $\mathrm{CO}_{2}$ or increase in heterotrophy from eutrophication (sensu Nixon 1995). For example, the alkalinity export from the Mississippi River to the Gulf of Mexico has increased by almost $50 \%$ over the last $50-100$ years due to increasing areas of cropland and increasing precipitation over the watershed (Raymond and Cole 2003; Raymond et al. 2008). Although freshwater discharge accounts for a large part of enhanced alkalinity export, concentrations of alkalinity in rivers have increased over time (Fig. 2a). Long-term records of river alkalinity from other areas (Fig. 2b, c) suggest a common global trend of increasing alkalinity exported from land to coastal ecosystems, which can lead to changes in $\mathrm{pH}$ on the order of $0.02-0.04 \mathrm{pH}$ units, sufficient to offset more than a decade of OA.

Inputs of organic matter, nitrogen and phosphorus to coastal ecosystems have increased greatly (Nixon 1995; Howarth et al. 1996; Conley 2000; Stedmon et al. 2006; Sharp 2010). Although eutrophication is the major concern related to these inputs, the $\mathrm{pH}$ of coastal waters is also influenced through the enhanced $\mathrm{CO}_{2}$ uptake from primary production and $\mathrm{CO}_{2}$ release from respiration associated with increased nutrient inputs. When in balance, primary production and respiration processes result in large diel variability (Table 2), but are essentially $\mathrm{CO}_{2}$-neutral; however, over longer timescales, spatial and/or temporal decoupling of these processes can change pH drastically (Borges and Gypens 2010; Provoost et al.
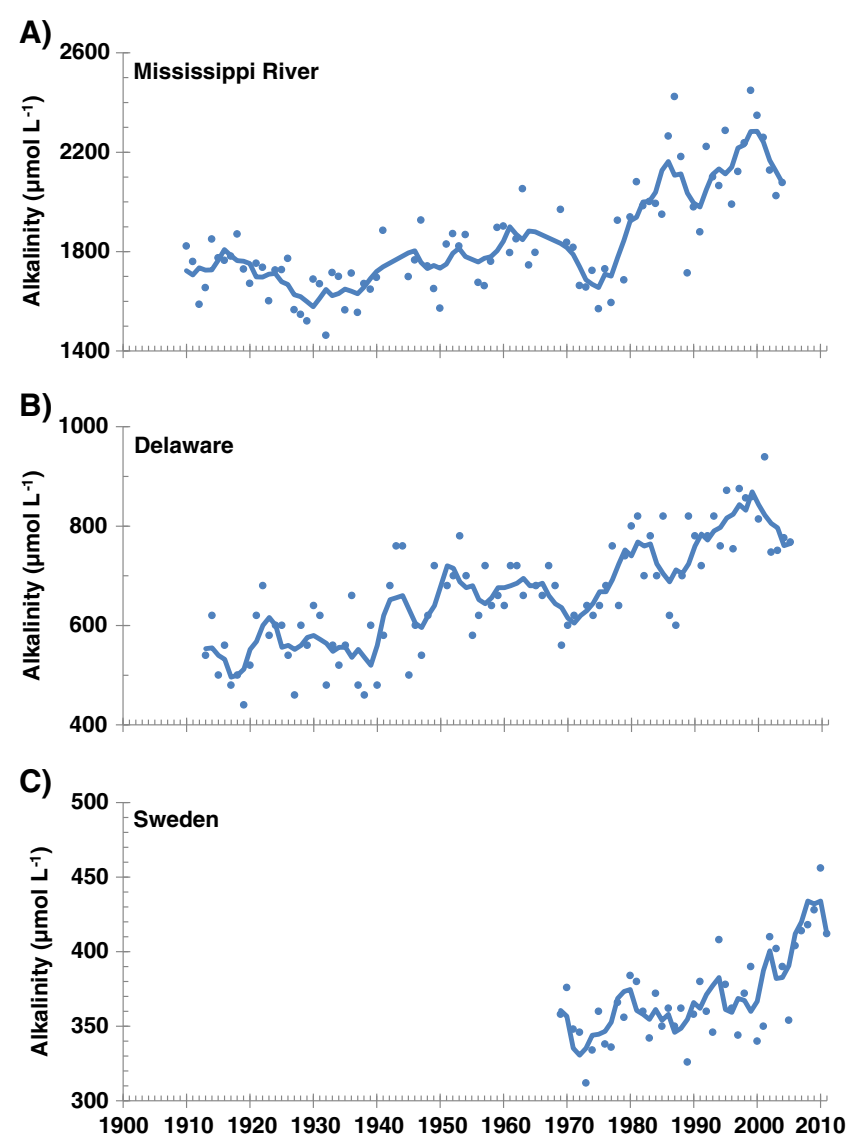

Fig. 2 Time series of alkalinity concentration in rivers from Mississippi River (a) (data from Raymond et al. 2008), Delaware River (b) (data from Sharp 2010) and Swedish rivers (c) (data from www.slu.se). Solid lines represent a 5-year moving average of the annual mean concentrations

2010; Cai et al. 2011). The effects of eutrophication on carbonate chemistry can exceed that of $\mathrm{OA}$ from anthropogenic $\mathrm{CO}_{2}$ by either increasing $\mathrm{pH}$, when enhanced $\mathrm{CO}_{2}$ uptake by primary producers prevails (Borges and Gypens 2010), or by decreasing $\mathrm{pH}$, where enhanced respiratory $\mathrm{CO}_{2}$ release prevails (Cai et al. 2011), a condition often associated with coastal hypoxia (Feely et al. 2010).

\section{Impacts on $\mathrm{pH}$ by Anthropogenic Changes in Coastal} Habitats

Coastal ecosystems contain multiple habitats that play an engineering role, affecting the physical and chemical properties of the ecosystem (Gutiérrez et al. 2011). These ecosystems include vegetated coastal habitats (seagrass meadows, macroalgal beds, salt marshes and mangroves) and coral and oyster reefs, among others (Gutiérrez et al. 2011). All coastal engineering communities support intense metabolic processes, including high primary production, respiration and calcification rates, thereby affecting $\mathrm{CO}_{2}$, $\mathrm{CO}_{3}{ }^{-}$, and alkalinity concentrations and surface water $\mathrm{pH}$. 
However, many metabolically intense coastal habitats are experiencing global declines in their abundance at rates in excess of $1 \%$ per year (Duarte et al. 2008; Ermgassen et al. 2013). These shifts in coastal habitats have major, although largely unreported, consequences for coastal $\mathrm{pH}$, affecting both their mean values and variability. Likewise, the restoration and redistribution of these habitats may affect $\mathrm{pH}$ in coastal ecosystems significantly. For instance, Arctic warming may allow the poleward spread of macroalgae and seagrasses, which could affect the $\mathrm{pH}$ of the coastal waters of these highly vulnerable regions seasonally.

\section{Current Trends in Open-Ocean and Coastal pH}

Open-ocean time series show that surface ocean $\mathrm{pH}$ has decreased on average by $0.1 \mathrm{pH}$ units since the industrial revolution (Caldeira and Wickett 2005; Orr et al. 2005; Doney et al. 2009), with open-ocean $\mathrm{pH}$ decreasing steadily over the last few decades at a rate of 0.0019 per year (Doney 2010). These trends match the expectations for OA driven by increasing levels of atmospheric $\mathrm{CO}_{2}$, confirming that this vector dominates the anthropogenic perturbation of $\mathrm{pH}$ in the open ocean. Model calculations (Orr et al. 2005) indicate that a decrease in carbonate mineral saturation states is occurring throughout the global open ocean and will impact the polar oceans first (Orr et al. 2005). During the summer of 2008, the Canada Basin of the Arctic Ocean was undersaturated with respect to aragonite (Yamamoto-Kawai et al. 2009).

However, observations of reported trends in surface water $\mathrm{pH}$ in coastal ecosystems reveal a variety of patterns, including periods of both increasing and decreasing $\mathrm{pH}$ (Fig. 3), in response to human alterations of the biogeochemical cycles in coastal ecosystems and their watersheds. A caveat in the interpretation of long-term trends in $\mathrm{pH}$ in coastal systems is that the measurement scale for $\mathrm{pH}$ is often not reported and that conventional measurement with glass electrodes along salinity gradients may introduce uncertainties (Provoost et al. 2010). Changes in salinity of 10 units can contribute an error in these $\mathrm{pH}$ determinations of about 0.03 units (Easley and Byrne, 2012), and the associated uncertainty in $\mathrm{pH}$ measured with an electrode calibrated at a single $\mathrm{pH}$ is \pm 0.3 units over a 3-unit change in pH (Easley and Byrne 2012; Waters 2012), indicative of \pm 0.03 units over the 0.3 -unit range typically observed in coastal systems. Collectively, these factors may introduce a random error of \pm 0.1 , generally much less than the inter-annual range of changes observed in coastal ecosystems (typically $>0.3$ ). As the patterns in coastal $\mathrm{pH}$ are based on averages over hundreds to thousands of measurements, the trends are nevertheless robust despite these uncertainties (Provoost et al. 2010).

Contrary to the reported trends in open-ocean $\mathrm{pH}$, none of the available records of long-term $\mathrm{pH}$ change in coastal

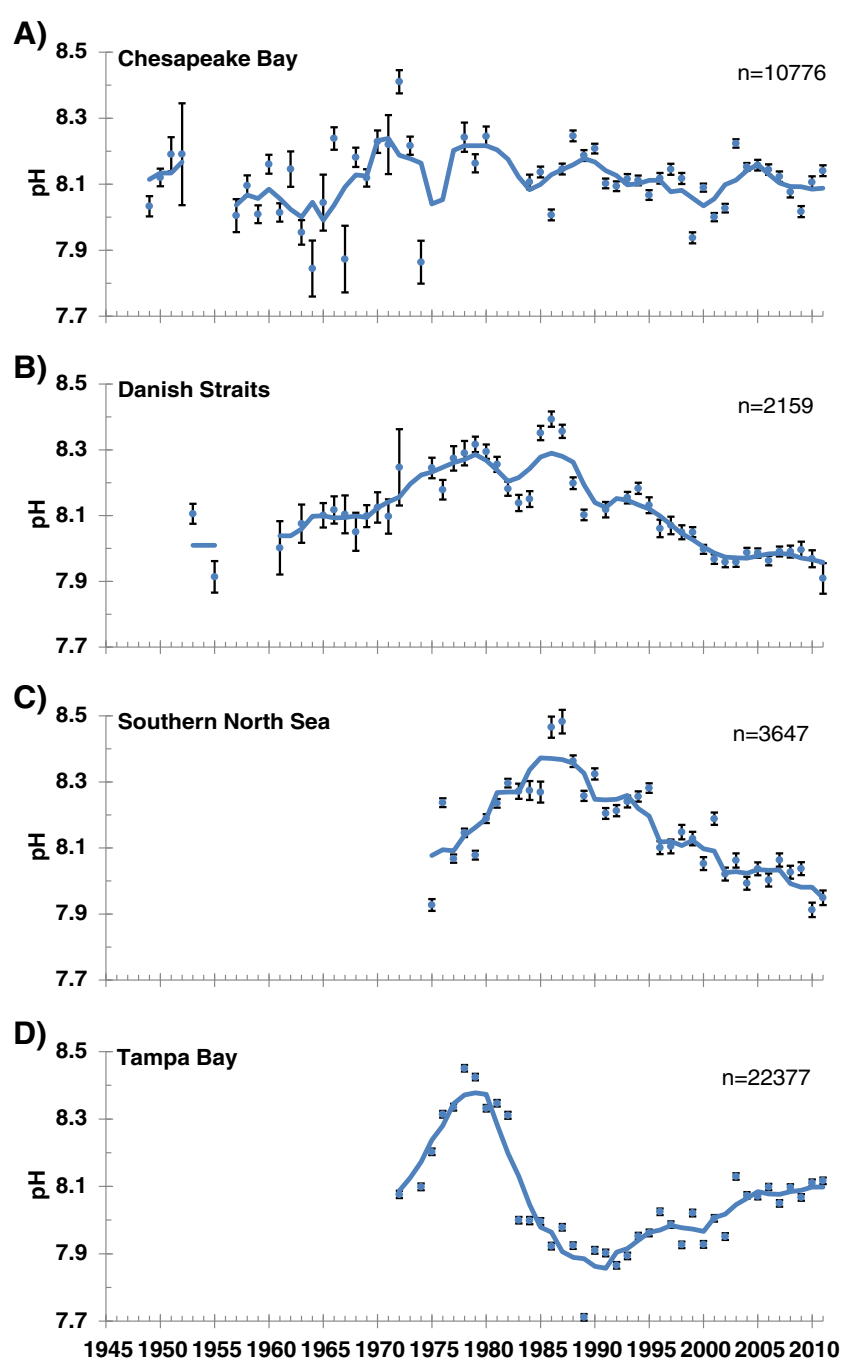

Fig. 3 Long-term trends in $\mathrm{pH}$ for selected coastal ecosystems: a Chesapeake Bay (mesohaline and polyhaline mainstem). b Danish Straits. c Southern North Sea. d Tampa Bay. Chesapeake Bay mainstem and Danish Straits are permanently stratified and trends were calculated for the surface layer $(0-10 \mathrm{~m})$, whereas trends in Southern North Sea and Tampa Bay represent the entire water column. Trends were calculated applying a statistical decomposition method (see Carstensen et al. 2006) to data downloaded from public databases (www.chesapeakebay.net (a), mads.dmu.dk (b), www.waterbase.nl (c) and www.tbep.org (d)). Symbols are annual means, with error bars showing the standard error of the means. Solid lines show the 5-year moving average of the annual means

ecosystems, that we are aware of, show the decline expected from OA alone (Provoost et al. 2010; Fig. 3). Long-term changes in coastal $\mathrm{pH}$ display patterns driven by a much more complex suite of anthropogenic impacts than those in the open ocean. In Chesapeake Bay, for example, $\mathrm{pH}$ in surface waters has not displayed a clear trend over the last 60 years, although it showed high variability before 1980 (Fig. 3a). This behaviour is presumably a combination of $\mathrm{pH}$ increases in the mesohaline mainstem and decreases in the polyhaline mainstem of the bay (Waldbusser et al. 2011). In 
the Susquehanna catchment, which delivers more than half of the freshwater input to Chesapeake Bay (Schubel and Pritchard 1986), reduced coal mining activity during the last century has led to increased river $\mathrm{pH}$ by 0.8 units (Raymond and Oh 2009), which, together with eutrophication, has partially counteracted processes that would reduce $\mathrm{pH}$ in the surface layer, such as OA and increased respiration.

The $\mathrm{pH}$ in the Danish Straits has also increased up to the mid-1980s (Fig. 3b), but then decreased by about 0.3 units in the surface layer over the last two and a half decades. This decrease is much steeper than can be explained by OA. Nutrient reduction plans, implemented since 1987, have reduced nitrogen inputs by $50 \%$ (Carstensen et al. 2006), but primary production remains high (Carstensen et al. 2011). The increase in surface $\mathrm{pH}$ before ca. 1985 is consistent with the trend in nitrogen inputs (Conley et al. 2009), whereas the subsequent decrease can be explained by enhanced ecosystem respiration.

Similar trends were observed in the southern North Sea. The $\mathrm{pH}$ values peaked around 1985, but declined thereafter by almost 0.4 units (Fig. 3c). This decline is far greater than can be explained by OA from anthropogenic $\mathrm{CO}_{2}$ alone, but oligotrophication was suggested as a potential reason (Provoost et al. 2010). Nutrient inputs to the area were reduced significantly and have reached levels similar to those in the early 1970 s, but phytoplankton biomass and, hence, primary production have not responded accordingly (Duarte et al. 2009; Carstensen et al. 2011). Thus, the large decline in $\mathrm{pH}$ could be due to a combination of OA, oligotrophication and enhanced respiration.

Conversely, $\mathrm{pH}$ in Tampa Bay displayed a somewhat different pattern, with strong increases up to 1980 followed by an almost instantaneous drop in $\mathrm{pH}$ and then a general increasing trend (Fig. 3d). Population growth in the Tampa Bay watershed has been high during this period, and nutrient removal from wastewater was not initiated until 1980 (Greening and Janicki 2006). A drop in primary production following this removal could explain the large decline in $\mathrm{pH}$ shortly thereafter throughout the bay. Seagrasses have expanded and water quality improved after implementation of the nutrient management plan, which should lead to enhanced $\mathrm{CO}_{2}$ uptake and $\mathrm{pH}$ increase.

Remarkably, these multi-decadal trends in coastal $\mathrm{pH}$ involve fluctuations of about $0.5 \mathrm{pH}$ units, much larger than the 0.1-unit decline of $\mathrm{pH}$ attributable to $\mathrm{OA}$ alone. Hence, we conclude that $\mathrm{OA}$ from anthropogenic $\mathrm{CO}_{2}$ is, to date, a relatively minor component of $\mathrm{pH}$ fluctuations in many coastal ecosystems, where enhanced primary production or respiration is often the primary driver. Moreover, changes could have been even larger, but competing watershed processes have buffered many of these changes.

\section{Future Trajectories of Open-Ocean and Coastal pH}

Scenarios of OA by anthropogenic $\mathrm{CO}_{2}$, driven by CGMs, predict a decline of $\mathrm{pH}$ by 0.3 units and a shoaling of the horizon for dissolution of carbonate minerals, particularly aragonite, by the end of the century as a result of increased anthropogenic $\mathrm{CO}_{2}$ in the ocean (Caldeira and Wickett 2003, 2005; Orr et al. 2005; Raven et al. 2005; Meehl et al. 2007). Model projections (McNeil and Matear 2008) predict that winters in the Southern Ocean will be characterized by undersaturated waters with respect to aragonite by around 2040. This projection is consistent with the models (Orr et al. 2005) which predict that the Southern Ocean surface waters will be undersaturated in aragonite throughout the year by 2050 .

Upwelling waters are corrosive naturally, but their $\mathrm{pH}$ may decline further over time due to OA. Accordingly, the $\mathrm{pH}$ of coastal waters affected by coastal upwelling is expected to decline in the future. A modelled simulation of the California Current upwelling region (Gruber et al. 2012) forecasts that summer-long undersaturation will occur in the top $60 \mathrm{~m}$ of the water column by year 2040 and that by 2050 aragonite saturation states greater than 1.5 will have disappeared, driving more than one half of the water column to undersaturation year-round. Additionally, the seafloor will be undersaturated year-round within the next 20-30 years.

However, global model projections have coarse resolution, with grid cell sizes of $200 \times 200 \mathrm{~km}$ or more, reflecting limitations of the ocean GCM component of global coupled climate and ocean circulation-biogeochemical models. Although models of improved resolution for ocean circulation are being developed, they do not yet incorporate biogeochemical properties. Consequently, models offering projections of future ocean $\mathrm{pH}$ and the saturation state of carbonate minerals only resolve adequately the open ocean and thus are incapable of resolving even the largest coastal ecosystems. Hence, the $\mathrm{pH}$ dynamics of coastal ecosystems are not captured adequately by current models projecting changes through the twenty-first century.

Attempts to extend current global models to coastal ecosystems may yield spurious results, unless these models capture other relevant processes, such as regional watershed processes and changes in landscapes at the ecosystem level, which are not tractable at the global scale. The difficulties in modelling $\mathrm{pH}$ changes in coastal ecosystems result not only from the resolution of global models but also from the greater complexity of $\mathrm{pH}$ regulation and the multiple vectors of anthropogenic impacts in $\mathrm{pH}$ operating in coastal ecosystems (Borges and Gypens 2010; Provoost et al. 2010; Barton et al. 2012; Cai et al. 2011; Hofmann et al. 2011; Mercado and Gordillo 2011; Waldbusser et al. 2011). Thus, predictions of future trajectories of $\mathrm{pH}$ in coastal ecosystems are still highly uncertain even though model predictions can 
provide reliable predictions for the future trajectories of open-ocean $\mathrm{pH}$ and, thereby, the open-ocean end-member affecting coastal $\mathrm{pH}$. Moreover, we argue that even the expectation that the component of coastal $\mathrm{pH}$ change associated with $\mathrm{OA}$ from anthropogenic $\mathrm{CO}_{2}$ will follow the same pattern as that in the open ocean is not necessarily supported. The reason for this conclusion is that, unlike the open ocean, $\mathrm{pCO}_{2}$ in coastal ecosystems is not necessarily in equilibrium with the atmosphere at even annual timescales and many coastal ecosystems emit $\mathrm{CO}_{2}$ into the atmosphere (Laruelle et al. 2010; Cai 2011). Calculations to resolve the anthropogenic component of $\mathrm{CO}_{2}$ are remarkably difficult for the coastal ocean, where the assumptions of the various methods (Sabine and Tanhua 2010) are not met, thereby precluding a direct calculation of the effect of anthropogenic $\mathrm{CO}_{2}$ on observed trends in coastal $\mathrm{pH}$. Calculations based on mixing between an open-ocean end-member displaying the trajectories predicted from OA and the freshwater endmember are also unreliable because $\mathrm{pH}$ and the carbon system do not necessarily behave conservatively within the coastal zone and because the freshwater end-member may also shift into the future.

Hence, paradoxically, we lack guidance on the future trajectories of $\mathrm{pH}$ in coastal ecosystems where some of the most vulnerable taxa to OA live (e.g. Doney et al. 2010; Hendriks et al. 2010a; Kroeker et al. 2010). Producing these forecasts requires the coupling of scenarios of global $\mathrm{CO}_{2}$ emissions with regional scenarios of likely changes in the inputs of inorganic and organic carbon, nutrients, acid and carbonate alkalinity from watersheds, and trajectories of habitat changes, thereby encompassing all relevant anthropogenic drivers of marine $\mathrm{pH}$ change. Coupling ocean and riverine biogeochemistry models is a first, necessary step, if a challenging one (Aufdenkampe et al. 2011). Nested models may help generate future scenarios for $\mathrm{pH}$ in coastal ecosystems at the regional level. These models would be composed of regional oceanographic modelling systems, forced both by GCMs, capturing the transport of anthropogenic $\mathrm{CO}_{2}$ to the coastal ocean and watershed processes. Integrating all changes that may occur on a watershed with the potential to impact coastal $\mathrm{pH}$ downstream (e.g. changes in land use, nutrient export, changes in runoff, changes in industrial and urban exports of alkalinity, mining activities) over a century timescale is challenging.

Depending on the balance between the anthropogenic drivers impacting marine $\mathrm{pH}$, the trajectories of future $\mathrm{pH}$ of some coastal ecosystems will range from steep acidification, several-fold faster than expected from anthropogenic $\mathrm{CO}_{2}$ emissions alone, to basification. Coastal ecosystems with attenuated or low-level watershed influences, such as Antarctic ecosystems and those adjacent to arid regions, are expected to show patterns consistent with OA by anthropogenic $\mathrm{CO}_{2}$ as they typically show little $\mathrm{pH}$ variability comparable to open-ocean waters (Hofmann et al. 2011; Matson et al. 2011; Falter et al. 2013). In general, increasing nutrient inputs, as expected throughout much of the developing world (Nixon 2009), may lead to increased $\mathrm{pH}$, whereas oligotrophication (Nixon 2009) may lead to acidification, adding to the same trend imposed by anthropogenic $\mathrm{CO}_{2}$ emission. Loss of vegetated coastal habitats should lead to a decline in $\mathrm{pH}$, whilst loss in the cover of corals and oyster reefs and regime shifts towards a great dominance of macroalgae may lead to increased $\mathrm{pH}$ (Anthony et al. 2011). The intensification of the hydrological cycle, with increased freshwater discharge, may also lead to decreased $\mathrm{pH}$, although this effect may be partially compensated by increased alkalinity export, depending on land use changes. This change is likely to be most dramatic in Arctic coastal waters, which are rapidly freshening due to the melting of ice on glaciers and permafrost (McPhee et al. 2009), accelerating OA and $\Omega_{\text {aragonite }}$ decline relative to the rates expected from anthropogenic $\mathrm{CO}_{2}$ alone (Tank et al. 2012). Freshening of the Arctic is so intense (McPhee et al. 2009) that the Arctic Ocean, progressively transformed into the Arctic Ocean Estuary (McClelland et al. 2012), is possibly the only ocean basin where OA by anthropogenic $\mathrm{CO}_{2}$ may not suffice to account for the observed and predicted $\mathrm{pH}$ and $\Omega_{\text {aragonite }}$ trends.

\section{Towards a Canonical Paradigm on Anthropogenic Impacts on Seawater $\mathbf{p H}$}

The concept of OA by anthropogenic $\mathrm{CO}_{2}$ suffices to accommodate the changes observed in the open ocean, where other perturbations such as atmospheric deposition of reactive sulfur and nitrogen play a minor role and where, perhaps with the exception of the Arctic Ocean, watershed perturbations are minimal. However, as concluded above, $\mathrm{pH}$ trajectories based on $\mathrm{OA}$ by anthropogenic $\mathrm{CO}_{2}$ cannot be extrapolated directly to most coastal ecosystems or much of the Arctic Ocean, except for ocean-dominated coastal ecosystems. We propose that $\mathrm{OA}$ due to anthropogenic $\mathrm{CO}_{2}$ emissions is largely an open-ocean syndrome and concur with the statement that "the role ocean acidification will play in estuaries may be different from the open ocean" (Feeley et al. 2010).

We propose here a new paradigm of anthropogenic impacts on seawater $\mathrm{pH}$. This new paradigm provides a canonical approach towards integrating the multiple components of anthropogenic forcing that lead to changes in coastal $\mathrm{pH}$. We believe that this paradigm, whilst accommodating that of OA by anthropogenic $\mathrm{CO}_{2}$, avoids the limitations the current $\mathrm{OA}$ paradigm faces to account for the dynamics of coastal ecosystems, where some ecosystems are not showing any acidification or basification trend whilst others show a much steeper acidification than expected for reasons entirely different from anthropogenic $\mathrm{CO}_{2}$ emissions. 
Human activities impacting watershed processes predate anthropogenic increases in atmospheric $\mathrm{CO}_{2}$ levels (Valiela 2006). Anthropogenic impacts on coastal $\mathrm{pH}$ driven by activities within the watershed may have been in operation over centuries to millennia (Valiela 2006; Hooke and Martín-Duque 2012), depending on the extent and intensity of human occupation. Hence, the current narrative of $\mathrm{OA}$ as an anthropogenic process driven by increased $\mathrm{CO}_{2}$ emissions to the atmosphere and subsequent dissolution in the ocean is only applicable partially to the coastal ocean where anthropogenic impacts on $\mathrm{pH}$ have multiple sources and vary in intensity and direction.

In contrast, the revised paradigm of anthropogenic impacts on seawater $\mathrm{pH}$ accommodates the full range of realized and future trends in $\mathrm{pH}$ of both open-ocean and coastal ecosystems and provides an improved framework to understand and model the dynamic $\mathrm{pH}$ environment of coastal ecosystems, with observed daily fluctuations often exceeding the range of mean $\mathrm{pH}$ values estimated for the open ocean as a consequence of OA during the twenty-first century by GCMs (Price et al. 2012; Tables 1 and 2).

Concern about the impacts that OA may pose to calcifying organisms has made a major contribution to an improved understanding of the drivers of changes in $\mathrm{pH}$, including those derived from natural processes as well as by the full range of anthropogenic drivers, including anthropogenic $\mathrm{CO}_{2}$ emissions. The new paradigm proposed here can accommodate the progress made through observations, modelling, and experimental and mechanistic research. Importantly, it provides a superior framework to assess the vulnerability of marine biota to changes in $\mathrm{pH}$. This approach allows the experimental and modelling frameworks that take account of the full suite of effects rather than just the scenarios derived from $\mathrm{OA}$ by anthropogenic $\mathrm{CO}_{2}$ alone, which may not adequately portray the range of possible future scenarios (Hendriks et al. 2010a, b; Hofmann et al. 2011), to be proposed. This paradigm may also guide major improvements in the detection and attribution of $\mathrm{OA}$ by anthropogenic $\mathrm{CO}_{2}$ as a component of climate change by identifying and apportioning components of $\mathrm{pH}$ trajectories attributable to factors other than anthropogenic $\mathrm{CO}_{2}$. Whereas detection of OA by anthropogenic $\mathrm{CO}_{2}$ has been achieved in open-ocean time series, we contend that it has not yet been achieved reliably in coastal ecosystems and that attribution of observed changes in vulnerable organisms to OA has been confounded in the past by failure to acknowledge the different components of anthropogenic impacts on $\mathrm{pH}$ possibly involved.

The paradigm of anthropogenic impacts on seawater $\mathrm{pH}$ can also help differentiate between primary drivers and symptoms. For instance, nutrient inputs and not $\mathrm{pH}$ are the force driving changes in $\mathrm{pH}$ in estuarine and coastal ecosystems derived from enhanced or suppressed net community production associated with eutrophication and oligotrophication processes. Hence, the master driver that needs to be managed is nutrient input, not $\mathrm{pH}$. Similarly, the enhanced photosynthetic activity of marine primary producers under elevated $\mathrm{CO}_{2}$ is often reported as an impact of OA, but the primary response is to $\mathrm{CO}_{2}$, not $\mathrm{pH}$. Indeed, enhanced photosynthetic activity with increased $\mathrm{CO}_{2}$ has been referred to for three decades as the $\mathrm{CO}_{2}$ fertilization effect (e.g. Tans et al. 1990). Referring to the $\mathrm{CO}_{2}$ fertilization effect when it happens in the ocean as OA generates confusion and misguides the proper understanding of the drivers.

A canonical paradigm of anthropogenic impacts on seawater $\mathrm{pH}$ can more effectively be used to formulate policies to conserve vulnerable calcifying organisms by acknowledging the various anthropogenic drivers of change in $\mathrm{pH}$, identifying regional and even local actions that may help vulnerable coastal organisms adapt to the impacts of OA by anthropogenic $\mathrm{CO}_{2}$ (Kelly et al. 2011) in parallel to global mitigation efforts. The strong controls that ecosystem metabolism and watershed processes exert on the $\mathrm{pH}$ in coastal ecosystems suggest that strategies based on the management of ecosystem components and watershed processes may help buffer the impacts of OA by anthropogenic $\mathrm{CO}_{2}$ locally, an option not available for the open ocean.

Acknowledgments This document results from contributions from MEDEICG projects funded by the Spanish Ministry of Economy and Competitiveness (CTM2009-07013), MedSEA of the FP7 of the EU (contract no. FP7-ENV-2010-265103), TEMSPATH Marie Curie Intra European Fellowship of the FP7 of the EU (254297: FP7-PEOPLE2009-IEF), the CSIRO Marine and Coastal Carbon Biogeochemistry Flagship Cluster, and the Baltic Nest Institute. We thank Jon Sharp and Peter Raymond for sharing alkalinity data on the Delaware River and Mississippi River, respectively, Wei Jun Cai and an anonymous reviewer for useful comments, and Iris C. Anderson and Wayne S. Gardner, co-editors in chief of Estuaries and Coasts, for useful advice and the invitation to write this piece.

\section{References}

Aufdenkampe, A.K., E. Mayorga, P.A. Raymond, J.M. Melack, S.C. Doney, S.R. Alin, R.E. Aalto, and K. Yoo. 2011. Riverine coupling of biogeochemical cycles between land, oceans, and atmosphere. Frontiers in Ecology and the Environment 9: 53-60.

Anthony, K., J.A. Kleypas, and J.P. Gattuso. 2011. Coral reefs modify their seawater carbon chemistry-implications for impacts of ocean acidification. Global Change Biology 17(12): 3655-3666.

Barnes, R., and P. Raymond. 2009. The contribution of agricultural and urban activities to inorganic carbon fluxes within temperate watersheds. Chemical Geology 266: 318-327.

Barton, A., B. Hales, G.G. Waldbusser, C. Langdon, and R.A. Feely. 2012. The Pacific oyster, Crassostrea gigas, shows negative correlation to naturally elevated carbon dioxide levels: Implications for near-term ocean acidification effects. Limnology and Oceanography 57: 698-710. 
Basterretxea, G., A. Tovar-Sanchez, A.J. Beck, P. Masqué, H.J. Bokuniewicz, R. Coffey, C.M. Duarte, J. Garcia-Orellana, E. Garcia-Solsona, L. Martinez-Ribes, and R. Vaquer-Sunyer. 2010. Submarine groundwater discharge to the coastal environment of a Mediterranean island (Majorca, Spain): ecosystem and biogeochemical significance. Ecosystems 13: 629-643. doi:10.1007/s10021010-9334-5.

Berner, Robert A., Martha R. Scott, and Catherine Thomlinson. 1970. Carbonate alkalinity in the pore waters of anoxic marine sediments. Limnology and Oceanography 15: 544-549.

Booth, J.A.T., E.E. McPhee-Shaw, P. Chua, E. Kingsley, M. Denny, R. Phillips, S.J. Bograd, L.D. Zeidberg, and W.F. Gilly. 2012. Natural intrusions of hypoxic, low $\mathrm{pH}$ water into nearshore marine environments on the California coast. Continental Shelf Research 45: 108-115.

Borges, A.V., and N. Gypens. 2010. Carbonate chemistry in the coastal zone responds more strongly to eutrophication than to ocean acidification. Limnology and Oceanography 55: 346-353.

Brake, S.S., K.A. Connors, and S.B. Romberger. 2001. A river runs through it: impact of acid mine drainage on the geochemistry of West Little Sugar Creek pre- and post-reclamation at the Green Valley coal mine, Indiana, USA. Environmental Geology 40: $1471-1481$

Brussaard, C.P.D., G.J. Gast, F.C. van Duyl, and R. Riegman. 1996. Impact of phytoplankton bloom magnitude on a pelagic microbial food web. Marine Ecology Progress Series 144: 211-221.

Cai, W.J. 2011. Estuarine and coastal ocean carbon paradox: $\mathrm{CO}_{2}$ sinks or sites of terrestrial carbon incineration? Annual Review of Marine Science 3: 123-145.

Cai, W.-J., X. Hu, W.-J. Huang, M.C. Murrell, J.C. Lehrter, S.E. Lohrenz, W.-C. Chou, W. Zhai, J.T. Hollibaugh, Y. Wang, P. Zhao, X. Guo, K. Gundersen, M. Dai, and G.-C. Gong. 2011. Acidification of subsurface coastal waters enhanced by eutrophication. Nature Geoscience 4: 766-770.

Caldeira, K., and R. Berner. 1999. Seawater $\mathrm{pH}$ and atmospheric carbon dioxide. Science 286(5447): 2043-2043.

Caldeira, K., and M.E. Wickett. 2003. Anthropogenic carbon and ocean pH. Nature 425: 365-365.

Caldeira, K., and M.E. Wickett. 2005. Ocean model predictions of chemistry changes from carbon dioxide emissions to the atmosphere and ocean. Journal of Geophysical Research 110: 1-12. C09S04.

Carstensen, J., D.J. Conley, J.H. Andersen, and G. Ærtebjerg. 2006. Coastal eutrophication and trend reversal: A Danish case study. Limnology and Oceanography 51: 398-408.

Carstensen, J., M. Sánchez-Camacho, C.M. Duarte, D. Krause-Jensen, and N. Marbà. 2011. Connecting the dots: responses of coastal ecosystems to changing nutrient concentrations. Environmental Science and Technology 45: 9122-9132.

Conley, D.J. 2000. Biogeochemical nutrient cycles and nutrient management strategies. Hydrobiologia 410: 87-96.

Conley, D.J., J. Carstensen, R. Vaquer-Sunyer, and C.M. Duarte. 2009. Ecosystem thresholds with hypoxia. Hydrobiologia 629: 21-29.

Crook, E.D., D. Potts, M. Rebolledo-Vieyra, L. Hernandez, and A. Paytan. 2012. Calcifying coral abundance near low-pH springs: implications for future ocean acidification. Coral Reefs 31:239-245.

Cullison-Gray, S.E., M.D. DeGrandpre, T.S. Moore, T.R. Martz, G.E. Friederich, and K.S. Johnson. 2011. Applications of in situ $\mathrm{pH}$ measurements for inorganic carbon calculations. Marine Chemistry 125: 82-90.

Cullison-Gray, S.E., M.D. DeGrandpre, C. Langdon, and J.E. Corredor. 2012. Short-term and seasonal $\mathrm{pH}, \mathrm{pCO}_{2}$ and saturation state variability in a coral-reef ecosystem. Global Biogeochemical Cycles 26(3): 1-13.

Cyronak, T., I.R. Santos, A. McMahon, and B.D. Eyre. 2013. Carbon cycling hysteresis in permeable carbonate sands over a diel cycle: implications for ocean acidification. Limnology and Oceanography 58(1): 131-143.

Dai, M., W. Zhai, W. Cai, J. Callahan, B. Huang, S. Shang, T. Huang, X. Li, Z. Lu, and W. Chen. 2008. Effects of an estuarine plumeassociated bloom on the carbonate system in the lower reaches of the Pearl River estuary and the coastal zone of the northern South China Sea. Continental Shelf Research 28: 1416-1423.

Delille, B., D. Delille, M. Fiala, C. Prevost, and M. Frankignoulle. 2000. Seasonal changes of $\mathrm{pCO}_{2}$ over a subantarctic Macrocystis kelp bed. Polar Biology 23: 706-716.

Doney, S.C. 2006. The dangers of ocean acidification. Scientific American 294: 58-65.

Doney, S.C. 2010. The growing human footprint on coastal and openocean biogeochemistry. Science 328: 1512-1516.

Doney, S.C., N. Mahowald, I. Lima, R.A. Feely, F.T. Mackenzie, J.F. Lamarque, and P.J. Rasch. 2007. Impact of anthropogenic atmospheric nitrogen and sulfur deposition on ocean acidification and the inorganic carbon system. Proceedings of the National Academy of Sciences 104(37): 14580-14585.

Doney, S.C., V.J. Fabry, R.A. Feely, and J.A. Kleypas. 2009. Ocean acidification: the other $\mathrm{CO}_{2}$ problem. Annual Review of Marine Science 1: 169-192.

Duarte, C.M., and J. Cerbrian. 1996. The fate of marine autotrophic production. Limnology and Oceanography 41(8): 1758-1766.

Duarte, C.M., W.C. Dennison, R.J. Orth, and T.J. Carruthers. 2008. The charisma of coastal ecosystems: addressing the imbalance. Estuaries and Coasts 31(2): 233-238.

Duarte, C.M., D.J. Conley, J. Carstensen, and M. Sánchez-Camacho. 2009. Return to Neverland: shifting baselines affect eutrophication restoration targets. Estuaries and Coasts 32: 29-36.

Easley, R.A., and R.H. Byrne. 2012. Spectrophotometric calibration of $\mathrm{pH}$ electrodes in seawater using purified $\mathrm{m}$-Cresol purple. Environmental Science \& Technology 46(9): 5018-5024.

Elbaz-Poulichet, F., N.H. Morley, A. Cruzado, Z. Velasquez, E.P. Achterberg, and C.B. Braungardt. 1999. Trace metal and nutrient distribution in an extremely low $\mathrm{pH}(2.5)$ river-estuarine system, the Ria of Huelva (South-west Spain). Science of the Total Environment 227(1): 73-83.

Ermgassen, P.S., M.D. Spalding, R.E. Grizzle, and R.D. Brumbaugh. 2013. Quantifying the loss of a marine ecosystem service: filtration by the eastern oyster in US estuaries. Estuaries and Coasts 36 (1): $36-43$.

Fabricius, K.E., C. Langdon, S. Uthicke, C. Humphrey, S. Noonan, G. De'ath, R. Okazaki, N. Muehllehner, M.S. Glas, and J.M. Lough. 2011. Losers and winners in coral reefs acclimatized to elevated carbon dioxide concentrations. Nature Climate Change 1: 165169.

Falkowski, P., R.J. Scholes, E. Boyle, J. Canadell, D. Canfield, J. Elser, N. Gruber, K. Hibbard, P. Högberg, S. Linder, F.T. Mackenzie, B. Moore III, T. Pedersen, Y. Rosenthal, S. Seitzinger, V. Smetacek, and W. Steffen. 2000. The global carbon cycle: a test of our knowledge of earth as a system. Science 290(5490): 291-296.

Falter, J.L., R.J. Lowe, Z. Zhang, and M. McCulloch. 2013. Physical and biological controls on the carbonate chemistry of coral reef waters: effects of metabolism, wave forcing, sea level, and geomorphology. PLoS One 8(1): e53303.

Feely, R.A., C.L. Sabine, J.M. Hernandez-Ayon, D. Ianson, and B. Hales. 2008. Evidence for upwelling of corrosive 'acidified' water onto the continental shelf. Science 320(5882): 1490-1492.

Feely, R.A., S.R. Alin, J. Newton, C.L. Sabine, M. Warner, A. Devol, C. Krembs, and C. Maloy. 2010. The combined effects of ocean acidification, mixing, and respiration on $\mathrm{pH}$ and carbonate saturation in an urbanized estuary. Estuarine Coastal Shelf Science 88: 442 449.

Fraile-Nuñez, E., M. González-Dávila, J. M. Santana-Casiano, J. Arístegui, I. J. Alonso-González, S. Hernández-León, M. J. 
Blanco, A. Rodríguez-Santana, A. Hernández-Guerra, M. D. Gelado-Caballero, F. Eugenio, J. Marcello, D. de Armas, J. F. Domínguez-Yanes, M. F. Montero, D. R. Laetsch, P. VélezBelchí, A. Ramos, A. V. Ariza, I. Comas-Rodríguez, and V.M. Benítez-Barrios. 2012. The submarine volcano eruption at the island of El Hierro: physical-chemical perturbation and biological response. Scientific Reports 2: Article No. 486.

Gattuso, J.P., C.E. Payri, M. Pichon, B. Delesalle, and M. Frankignoulle. 1997. Primary production, calcification, and airsea $\mathrm{CO}_{2}$ fluxes of a macroalgal-dominated coral reef community. Journal of Phycology 33: 729-738.

Gattuso, J.P., M. Frankignoulle, and R. Wollast. 1998. Carbon and carbonate metabolism in coastal aquatic ecosystems. Annual Review of Ecology and Systematics 29:405-434.

Greening, H., and A. Janicki. 2006. Toward reversal of eutrophic conditions in a subtropical estuary: water quality and seagrass response to nitrogen loading reductions in Tampa Bay, Florida, USA. Environmental Management 38: 163-178.

Gruber, N., C. Hauri, Z. Lachkar, D. Loher, T.L. Frölicher, and G.-K. Plattner. 2012. Rapid progression of ocean acidification in the California Current System. Science 337(6091): 220-223.

Gutiérrez, J.L., C.G. Jones, J.E. Byers, K.K. Arkema, K. Berkenbusch, J.A. Commito, C.M. Duarte, S.D. Hacker, J.G. Lambrinos, I.E. Hendriks, P.J. Hogarth, M.G. Palomo, and C. Wild. 2011. Physical ecosystem engineers and the functioning of estuaries and coasts. In: E. Wolanski, D.S. McLusky (eds). Treatise on estuarine and coastal science 7:53-81. Waltham: Academic.

Guo, X., W.-J. Cai, W.-J. Huang, Y. Wang, F. Chen, M.C. Murrell, S.E. Lohrenz, L.-Q. Jiang, M. Dai, J. Hartmann, Q. Lin, and R. Culp. 2012. Carbon dynamics and community production in the Mississippi River plume. Limnology and Oceanography 57(1): $1-17$.

Hall-Spencer, J.M., R. Rodolfo-Metalpa, S. Martin, E. Ransome, M. Fine, S.M. Turner, S.J. Rowley, D. Tedesco, and M.-C. Buia. 2008. Volcanic carbon dioxide vents show ecosystem effects of ocean acidification. Nature 454(7200): 96-99.

Hendriks, I.E., C.M. Duarte, and M. Álvarez. 2010a. Vulnerability of marine biodiversity to ocean acidification: a meta-analysis. Estuarine, Coastal and Shelf Science 86: 157-164.

Hendriks, I.E., and C.M. Duarte. 2010b. Ocean acidification: separating evidence from judgment: a reply to Dupont et al. Estuarine, Coastal and Shelf Science 89: 186-190.

Hines, M.E., S.L. Knollmeyer, and J.B. Tugel. 1989. Sulfate reduction and other sedimentary biogeochemistry in a northern New England salt marsh. Limnology and Oceanography 34: $578-590$.

Hofmann, G.E., J.E. Smith, K.S. Johnson, U. Send, L.A. Levin, F. Micheli, A. Paytan, N.N. Price, B. Peterson, Y. Takeshita, P.G. Matson, E.D. Crook, K.J. Kroeker, M.C. Gambi, E.B. Rivest, C.A. Frieder, P.C. Yu, and T.R. Martz. 2011. High-frequency dynamics of ocean $\mathrm{pH}$ : a multi-ecosystem comparison. PLoS One 6(12): e28983.

Hönisch, Bärbel, A. Ridgwell, D.N. Schmidt, E. Thomas, S.J. Gibbs, A. Sluijs, R. Zeebe, L. Kump, R.C. Martindale, S.E. Greene, W. Kiessling, J. Ries, J.C. Zachos, D.L. Royer, S. Barker, T.M. Marchitto Jr., R. Moyer, C. Pelejero, P. Ziveri, G.L. Foster, and B. Williams. 2012. The geological record of ocean acidification. Science 335(6072): 1058-1063.

Hooke, R.L., and J.F. Martín-Duque. 2012. Land transformation by humans: a review. GSA Today 22(12): 4-10.

Howarth, R.W., G. Billen, D. Swaney, A. Townsend, N. Jaworski, K. Lajtha, J.A. Downing, R. Elmgren, N. Caraco, T. Jordan, F. Berendse, J. Freney, V. Kudeyarov, P. Murdoch, and Z. ZhaoLiang. 1996. Regional nitrogen budgets and riverine N \& P fluxes for the drainages to the North Atlantic Ocean: natural and human influences. Biogeochemistry 35: 75-139.
Hu, X., and W.J. Cai. 2003. An assessment of ocean margin anaerobic processes on oceanic alkalinity budget. Global Biogeochemical Cycles 25:GB3003.

Invers, O., J. Romero, and M. Pérez. 1997. Effects of $\mathrm{pH}$ on seagrass photosynthesis: a laboratory and field assessment. Aquatic Botany 59: $185-194$.

Johnson, V.R., C. Brownlee, R.E.M. Rickaby, M. Graziano, M. Milazzo, and J.M. Hall-Spencer. 2013. Responses of marine benthic microalgae to elevated $\mathrm{CO}_{2}$. Marine Biology. doi:10.1007/ s00227-011-1840-2.

Johnston, S.G., R.T. Bush, L.A. Sullivan, E.D. Burton, D. Smith, M.A. Martens, A.E. McElnea, C.R. Ahern, B. Powell, L.P. Stephens, S.T. Wilbraham, and S. van Heel. 2009. Changes in water quality following tidal inundation of coastal lowland acid sulfate soil landscapes. Estuarine, Coastal and Shelf Science 81(2): 257-266.

Kayanne, H., H. Hata, S. Kudo, H. Yamano, A. Watanabe,Y. Ikeda, K. Nozaki,K. Kato, A. Negishi, and H. Saito. 2005. Seasonal and bleaching-induced changes in coral reef metabolism and $\mathrm{CO}_{2}$ flux. Global Biogeochemical Cycles 19:GB3015.

Kelly, R.P., M.M. Foley, W.S. Fisher, R.A. Feely, B.S. Halpern, G.G. Waldbusser, and M.R. Caldwell. 2011. Mitigating local causes of ocean acidification with existing laws. Science 332(6033): 10361037.

Kelly, M.W., and G.E. Hofmann. 2012. Adaptation and the physiology of ocean acidification. Functional Ecology. doi:10.1111/j.13652435.2012.02061.x

Kroeker, K.J., R.L. Kordas, R.N. Crim, and G.G. Singh. 2010. Metaanalysis reveals negative yet variable effects of ocean acidification on marine organisms. Ecology Letters 13(11): 1419-1434.

Laruelle, G.G., H.H. Dürr, C.P. Slomp, and A.V. Borges. 2010. Evaluation of sinks and sources of $\mathrm{CO}_{2}$ in the global coastal ocean using a spatially-explicit typology of estuaries and continental shelves. Geophysical Research Letters 37(15): L15607.

Manzello, D.P. 2010. Ocean acidification hotspots: spatiotemporal dynamics of the seawater $\mathrm{CO}_{2}$ system of eastern Pacific coral reefs. Limnology and Oceanography 55(1): 239-248.

Matson, P.G., T.R. Martz, and G.E. Hofmann. 2011. High-frequency observations of $\mathrm{pH}$ under Antarctic Sea ice in the southern Ross Sea. Antarctic Science 23: 607-613.

McClelland, J.W., R.M. Holmes, K.H. Dunton, and R.W. Macdonald. 2012. The Arctic Ocean estuary. Estuaries and Coasts 35(2): 353-368.

McNeil, B.I., and R.J. Matear. 2008. Southern Ocean acidification: a tipping point at 450-ppm atmospheric $\mathrm{CO}_{2}$. PNAS 105(48): $18860-4$.

McPhee, M.G., A. Proshutinsky, J.H. Morison, M. Steele, and M.B. Alkire. 2009. Rapid change in freshwater content of the Arctic Ocean. Geophysical Research Letters 36(10): L10602.

Menéndez, M., M. Martínez, and F.A. Comínet. 2001. A comparative study of the effect of $\mathrm{pH}$ and inorganic carbon resources on the photosynthesis of three floating macroalgae species of a Mediterranean coastal lagoon. Journal of Experimental Marine Biology and Ecology 256: 123-136.

Meehl, G.A., T.F. Stocker, W.D. Collins, P. Friedlingstein, A.T. Gaye, J.M. Gregory, A. Kitoh, R. Knutti, J.M. Murphy, A. Noda, S.C.B. Raper,I.G. Watterson, A.J. Weaver, and Z.-C. Zhao. 2007. Global climate projections. In: S. Solomon, D. Qin, M. Manning, Z. Chen, M. Marquis, K.B. Averyt, M. Tignor, and H.L. Miller (eds) Climate Change 2007: the physical science basis. Contribution of Working Group I to the Fourth Assessment Report of the Intergovernmental Panel on Climate Change. Cambridge, UK: Cambridge University Press.

Melzner, F., J. Thomsen, W. Koeve, A. Oschlies, M.A. Gutowska, H.W. Bange, H.P. Hansen, and A. Körtzinger. 2013. Future ocean acidification will be amplified by hypoxia in coastal habitats. Marine Biology. doi:10.1007/s00227-012-1954-1. 
Mercado, J.M., and F.J.L. Gordillo. 2011. Inorganic carbon acquisition in algal communities: are the laboratory data relevant to the natural ecosystems? Photosynthetic Research 109: 257-267.

Middelboe, A.L., and P.J. Hansen. 2007. High pH in shallow-water macroalgal habitats. Marine Ecology Progress Series 338: 107-117.

Nakamura, T., and T. Nakamori. 2009. Estimation of photosynthesis and calcification rates at a fringing reef by accounting for diurnal variations and the zonation of coral reef communities on reef flat and slope: a case study for the Shiraho reef, Ishigaki Island, southwest Japan. Coral Reefs 28: 229-250.

Nixon, S.W. 1995. Coastal marine eutrophication: a definition, social causes, and future concerns. Ophelia 41: 199-219.

Nixon, S.W., C.A. Oviatt, J. Garber, and V. Lee. 1976. Diel metabolism and nutrient dynamics in a salt marsh embayment. Ecology 57: $740-750$.

Nixon, S.W. 2009. Eutrophication and the macroscope. In: J.H. Andersen and D.J. Conley (eds), Eutrophication in coastal ecosystems. Developments in Hydrobiology, 207:5-19.

Oh, N.-H., and P. Raymond. 2006. Contribution of agricultural liming to riverine bicarbonate export and $\mathrm{CO}_{2}$ sequestration in the Ohio River basin. Global biogeochemical cycles 20.

Ohde, S., and R. van Woesik. 1999. Carbon dioxide flux and metabolic processes of a coral reef, Okinawa. Bulletin of Marine Science 65: $559-576$.

Orr, J.C., V.J. Fabry, O. Aumont, L. Bopp, S.C. Doney, R.A. Feely, A. Gnanadesikan, N. Gruber, A. Ishida, and F. Joos. 2005. Anthropogenic ocean acidification over the twenty-first century and its impact on calcifying organisms. Nature 437: 681-686.

Pagani, M., D. Lemarchand, A. Spivack, and J. Gaillardet. 2005. A critical evaluation of the boron isotope-pH proxy: the accuracy of ancient ocean $\mathrm{pH}$ estimates. Geochimica et Cosmochimica Acta 69(4): 953-961.

Park, K., D.W. Hood, and H.T. Odum. 1958. Diurnal pH variations in Texas bays, and its application to primary production estimation. Publications of the Institute of Marine Science, University of Texas 5: 47-64.

Pearson, P.N., and M.R. Palmer. 2000. Atmospheric carbon dioxide concentrations over the past 60 million years. Nature 406(6797): 695-699.

Pelejero, C., E. Calvo, and O. Hoegh-Guldberg. 2010. Paleoperspectives on ocean acidification. Trends in Ecology \& Evolution 25(6): 332-344.

Powell, B., and M. Martens. 2005. A review of acid sulfate soil impacts, actions and policies that impact on water quality in Great Barrier Reef catchments, including a case study on remediation at East Trinity. Marine Pollution Bulletin 51(1): 149-164.

Price, N.N., T.R. Martz, R.E. Brainard, and J.E. Smith. 2012. Diel variability in seawater $\mathrm{pH}$ relates to calcification and benthic community structure on coral reefs. PLoS One 7: e43843.

Provoost, P., S. van Heuven, K. Soetaert, R.W.P.M. Laane, and J.J. Middelburg. 2010. Seasonal and long-term changes in $\mathrm{pH}$ in the Dutch coastal zone. Biogeosciences 7: 3869-3878.

Raven, J., K. Caldeira, H. Elderfield, O. Hoegh-Guldberg, P. Liss, U. Riebesell, J. Shepherd, C. Turley, and A. Watson. 2005. Ocean acidification due to increasing atmospheric carbon dioxide. The Royal Society.

Raymond, P.A., and J.J. Cole. 2003. Increase in the export of alkalinity from North America's largest river. Science 301: 88-91.

Raymond, P.A., N.-H. Oh, R.E. Turner, and W. Broussard. 2008. Anthropogenically enhanced fluxes of water and carbon from the Mississippi River. Nature 451: 449-452.

Raymond, P.A., and N.H. Oh. 2009. Long term changes of chemical weathering in rivers heavily impacted from acid mine drainage: insights on the impact of coal mining on regional and global carbon and sulfur budgets. Earth and Planetary Science Letters 284: $50-56$.

Ries, J.B., A.L. Cohen, and D.C. McCorkle. 2009. Marine calcifiers exhibit mixed responses to $\mathrm{CO}_{2}$-induced ocean acidification. Geology 37(12): 1131-1134.

Sabine, C.L., and T. Tanhua. 2010. Estimation of anthropogenic $\mathrm{CO}_{2}$ inventories in the ocean. Annual Reviews of Marine Science 2: 175-198.

Salisbury, J., M. Green, C. Hunt, and J. Campbell. 2008. Coastal acidification by rivers: a threat to shellfish? Eos, Transactions American Geophysical Union 89(50):513

Santos, I.R., R.N. Glud, D. Maher, D. Erler and B.D. Eyre. 2011. Diel coral reef acidification driven by porewater advection in permeable carbonate sands. Heron Island, Great Barrier Reef. Geophysical Research Letters 38:L03604.

Schmalz, R.F., and F.J. Swanson. 1969. Diurnal variation in the carbonate saturation of seawater. Journal of Sedimentary Petrology 39: 255-267.

Schubel, J.R., and D.W. Pritchard. 1986. Responses of Upper Chesapeake Bay to variations in discharge of the Susquehanna River. Estuaries 9: 236-249.

Semesi, I.S., S. Beer, and M. Björk. 2009. Seagrass photosynthesis controls rates of calcification and photosynthesis of calcareous macroalgae in a tropical seagrass meadow. Marine Ecology Progress Series 382: 41-47.

Sharp, J. 2010. Estuarine oxygen dynamics: what can we learn about hypoxia from long-time records in the Delaware Estuary? Limnology and Oceanography 55: 535-548.

Silverman, J., B. Lazar, and J. Erez. 2007. Effect of aragonite saturation, temperature, and nutrients on the community calcification rate of a coral reef. Journal of Geophysical Research-Oceans 112: C05004.

Spilling, K. 2007. Dense sub-ice bloom of dinoflagellates in the Baltic Sea, potentially limited by high $\mathrm{pH}$. Journal of Plankton Research 29: 895-901.

Stedmon, C., S. Markager, M. Søndergaard, T. Vang, A. Laubel, N.H. Borch, and A. Windelin. 2006. Dissolved organic matter (DOM) export to a temperate estuary: Seasonal variations and implications of land use. Estuaries and Coasts 29: 388400.

Steffen, W., P.J. Crutzen, and J.R. McNeill. 2007. The Anthropocene: are humans now overwhelming the great forces of nature. Ambio: A Journal of the Human Environment 36(8): 614-621.

Stevens, P.W. 2002. Test of salt marsh as a site of production and export of fish biomass with implications for impoundment management and restoration. PhD thesis, University of Florida.

Suzuki, A., H. Kawahata, and K. Goto. 1997. Reef water $\mathrm{CO}_{2}$ system and carbon cycle in Majuro Atoll, the Marshall Islands in the central Pacific. Proceedings of the 8th International Coral Reef Symposium 1:971-976.

Taguchi, F., and T. Fujiwara. 2010. Carbon dioxide stored and acidified low oxygen bottom waters in coastal seas, Japan. Estuarine, Coastal and Shelf Science 86: 429-433.

Tank, S.E., P.A. Raymond, R.G. Striegl, J.W. McClelland, R.M. Holmes, G.J. Fiske, and B.J. Peterson. 2012. A land-to-ocean perspective on the magnitude, source and implication of DIC flux from major Arctic rivers to the Arctic Ocean. Global Biogeochemical Cycles 26(4): GB4018.

Tans, P.P., I.Y. Fung, and T. Takahashi. 1990. Observational constraints on the global atmospheric $\mathrm{CO}_{2}$ budget. Science 247: 14311438.

Tyrrell, T., and R.E. Zeebe. 2004. History of carbonate ion concentration over the last 100 million years. Geochimica et Cosmochimica Acta 68(17): 3521-3530.

Valiela, I. (2006). Global coastal change. Malden, MA: Blackwell. 
Watanabe, A., H. Kayanne, H. Hata, S. Kudo, K. Nozaki, K. Kato, A.A. Negishi, Y. Ikeda, and H. Yamano. 2006. Analysis of the seawater $\mathrm{CO}_{2}$ system in the barrier reef-lagoon system of Palau using total alkalinity-dissolved inorganic carbon diagrams. Limnology and Oceanography 51: 1614-1628.

Waldbusser, G.G., E.P. Voigt, H. Bergschneider, M.A. Green, and R.I. Newell. 2011. Biocalcification in the eastern oyster (Crassostrea virginica) in relation to long-term trends in Chesapeake Bay $\mathrm{pH}$. Estuaries and Coasts 34(2): 221-231.

Waters, J.F. 2012. Measurement of seawater pH: a theoretical and analytical investigation. Open Access Dissertations Paper 908.

Wei, G., L. Xie, W. Wu, W.Deng and M. McCulloch. 2011. Seawater $\mathrm{pH}$ records from a fringe coral reef in southern Hainan Island, the Northern South China Sea: implications for ocean acidification. Goldschmidt Conference Abstract. Mineralogical Magazine, p. 2141.

West, T.O., and A.C. McBride. 2005. The contribution of agricultural lime to carbon dioxide emissions in the United States: dissolution, transport, and net emissions. Agriculture, Ecosystems \& Environment 108: 145-156.

Wilson, B.P., I. White, and M.D. Melville. 1999. Floodplain hydrology, acid discharge and change in water quality associated with a drained acid sulfate soil. Marine and Freshwater Research 50(2): 149-157.

Wolaver, T.G., J. Zieman, and B. Kjerfve. 1986. Factors affecting short-term variability in sediment $\mathrm{pH}$ as a function of marsh elevation in a Virginia mesohaline marsh. Journal of Experimental Marine Biology and Ecology 101: 227-237.

Yamamoto-Kawai, M., F.A. McLaughlin, E.C. Carmack, S. Nishino, and K. Shimada. 2009. Aragonite undersaturation in the Arctic Ocean: effects of ocean acidification and sea ice melt. Science 326: 1098-100.

Yates, K.K., and R.B. Halley. 2006. $\mathrm{CO}_{2}$ concentration and $\mathrm{pCO}_{2}$ thresholds for calcification and dissolution on the Molokai reef flat, Hawaii. Biogeosciences 3: 357-369.

Zhai, W.D., H.D. Zhao, N. Zheng, and Y. Xu. 2012. Coastal acidification in summer bottom oxygen-depleted waters in northwesternnorthern Bohai Sea from June to August in 2011. Chinese Science Bulletin 57: 1062-1068. 